\title{
The Treatment of Primary IgA Nephropathy
}

\section{Dongxu Song, Shengqiang $\mathrm{Yu}^{*}$ and Changlin $\mathrm{Mei}^{*}$}

Division of Nephrology, Nephrology Institute of PLA, Shanghai Changzheng Hospital, Second Military Medical University, Shanghai, China

\begin{abstract}
IgA Nephropathy (IgAN) is a very common glomerulonephritis worldwide, especially in Asia, which is an important cause of progressive kidney disease with $25-30 \%$ of patients developing end-stage renal disease within 20 years of diagnosis. IgA nephropathy can be in different age bracket onset, but mainly in adults. The treatment of primary $\lg \mathrm{A}$ nephropathy we mentioned in this article is only for adults. The optimal treatment for IgAN remains poorly defined. The current treatment depends on the assessment of proteinuria, blood pressure, estimated Glomerular Filtration Rate (eGFR) and pathological features, including antiproteinuric and antihypertensive therapy, corticosteroids, immunosuppressive agents, fish oil and tonsillectomy. Compounded by the relative lack in IgAN of Randomized Controlled Trials (RCTs), there is no consensus on the use of corticosteroids, immunosuppressive agents, fish oil and tonsillectomy for treatment. The treatment of primary IgA Nephrology was reviewed from these aspects in this article.
\end{abstract}

Keywords: Nephropathy; Glomerular filtration rate; Immunoglobulin

\section{Introduction}

IgA nephropathy is a chronic form of glomerulonephritis characterized by deposits of predominantly immunoglobulin $\mathrm{A}$ in the glomeruli. Deposits of complement C3 and immunoglobulin $\mathrm{G}$ are also often found. This disease can be divided into two types, the primary IgA nephropathy which is caused by kidney itself, and secondary IgA nephropathy, that the glomerular immunoglobulin A deposits are associated with Henoch-Schönlein purpura, HIV infection, negative serum spinal arthritis, tumor, etc. The classic presentation (in $40-50 \%$ of the cases) is episodic hematuria which usually starts within a day or two of a non-specific upper respiratory tract infection as opposed to post-streptococcal glomerulonephritis which occurs some time (weeks) after initial infection. Loin pain can also occur. Renal function usually remains normal, though rarely, acute renal failure may occur in younger adults. Nephrotic syndrome occurs in around $5 \%$ of cases. Acute renal failure may result from acute tubular necrosis as a consequence of macroscopic hematuria or superimposed crescentic nephritis and is seen during the course of the disease in $5 \%$ of cases. $5 \%$ of the patients who probably had longstanding undetected microscopic hematuria and/or proteinuria developed to chronic kidney disease [1,2]. Its diagnosis is based on histopathologic and immunoflourescence studies on renal biopsy. ACEI or ARB drugs, antithrombotic agents, steroid, immunosuppressive agents, fish oil and tonsillectomy are the present therapy strategies for primary IgA nephropathy in adults. Until now, there is insufficient evidence for the additional use of some of the above drugs. In this review, we focus on the treatment in primary IgA nephropathy.

\section{ACEI or ARB Drugs}

The most common mechanism of deterioration of renal function is caused by glomerular hypertension and hyperfiltration that arise from a reduction in the remaining normal, uninjured nephron by glomerular obsolescence [2]. Proteinuria and hypertension are two of the strongest predictors of outcome in IgAN, which can be treated by renin-angiotensin-aldosterone system inhibitors (RASIs), such as Angiotensin-Converting Enzyme Inhibitors (ACEIs) and Angiotensin Receptor Blockers (ARBs) to suppress glomerular hypertension and hyper filtration (Table 1). The KDIGO 2012 recommends long term ACEI or ARB treatment when proteinuria is $>0.5 \mathrm{~g} / \mathrm{d}$ [3]. The dosage of the drug depends on the blood pressure and proteinuria level. An RCT that lasted 6 years included 207 patients suggested that high-dose ARB therapy is possibility of recovery of renal function on long-term high-dose therapy compared with normal dose ARB and ACEI [4]. Another retrospective study in Japan suggested that ACEIs or ARBs were effective for long-term renal survival of advanced IgAN (eGFR< $60 \mathrm{ml} / \mathrm{min}$ ), although proteinuria and blood pressure did not decrease [5]. But a recent RCT which used ramipril $2.5 \mathrm{mg}$ daily to treat IgAN patients with proteinuria $<0.5 \mathrm{~g} / \mathrm{d}$ followed for 5 years indicated that compared with no treatment, ACEI therapy did not offer any benefit in these patients [6]. Commonly, no recommendation on the use of the combination therapy ACEI plus ARB is possible in IgAN patients. But a meta-analysis included 6 RCTs showed that combination therapy ACEI plus ARB may provide more benefits to IgAN patients for reducing daily proteinuria [7]. In our opinion, these RCTs did not have a large sample and a long follow-up, the risk of hyperkalemia also should be put into grave concern, so the long-term effects of these agents on renal outcomes, and safety needed to be established.

\section{Corticosteroids}

The other important mechanism of deterioration of renal function is caused by which aberrantly glycosylated serum IgA1 causes mesangial IgA deposition and inflammatory changes, such as crescent formation and endothelial hyper cellularity in the glomeruli [2]. This can be treated by steroid therapy to suppress inflammatory changes in the glomeruli and interstitium [8] (Table 2). IgAN patients with persistent proteinuria $\geq 1 \mathrm{~g} / \mathrm{d}$, despite optimized supportive care, should be given a 6-month course of corticosteroids if GFR is above $50 \mathrm{ml} / \mathrm{min}$. Compared with support therapy alone, steroid therapy for six months provided additional benefits in preventing the progression of renal disease [9-11]. The steroid therapy consists of two strategies, pulse plus oral steroids and oral steroids only. The effect of two strategies appears to be equal. The risk for adverse events increases in IgAN patients with steroid therapy, so the safety needs high-quality trial with a large sample size [12]. Strictly alternating or low-dose corticosteroid therapy is ineffective [13-15].

${ }^{*}$ Corresponding author: Shengqiang Yu, Division of Nephrology, Nephrology Institute of PLA, Shanghai Changzheng Hospital, Second Military Medical University, Shanghai, China, Tel: 00862181885399; E-mail: ysqdd@hotmail.com

Received November 03, 2013; Accepted November 30, 2013; Published December 04, 2013

Citation: Song D, Yu S, Mei C (2013) The Treatment of Primary IgA Nephropathy. J Nephrol Ther 3: 144. doi:10.4172/2161-0959.1000144

Copyright: $\odot 2013$ Song D, et al. This is an open-access article distributed under the terms of the Creative Commons Attribution License, which permits unrestricted use, distribution, and reproduction in any medium, provided the original author and source are credited. 


\begin{tabular}{|c|c|c|c|c|c|}
\hline Published time & Research type & Research object & Follow-up time & Treatment & Outcome \\
\hline $2009[4]$ & $\begin{array}{l}\text { Prospective } \\
\text { cohort study }\end{array}$ & 207 patients with IgAN & 6 years & $\begin{array}{l}\text { High-dose losartan }(200 \mathrm{mg} / \mathrm{d}) \text {, normal- } \\
\text { dose }(100 \mathrm{mg} / \mathrm{d}) \text {, normal-dose enalapril }(20 \\
\mathrm{mg} / \mathrm{d}) \text { and low-dose }(10 \mathrm{mg} / \mathrm{d})\end{array}$ & $\begin{array}{l}\text { Patients on high-dose ARB had significantly } \\
\text { higher eGFR }(p<0.0005) \text { and lower } \\
\text { proteinuria }(p<0.005)\end{array}$ \\
\hline $2011[5]$ & $\begin{array}{l}\text { Retrospective } \\
\text { cohort study }\end{array}$ & $\begin{array}{l}66 \text { IgAN patients with an } \\
\text { eGFR }<60 \mathrm{ml} / \mathrm{min}\end{array}$ & $2-17$ years & $\begin{array}{l}\text { ACEl group }(n=20), \text { ARB group }(n=23) \\
\text { Control group }(n=23, \text { treated with } \\
\text { antiplatelet agents) }\end{array}$ & $\begin{array}{l}\text { Renal survival rate was significantly higher in } \\
\text { the ACEI or ARB groups than in the control } \\
\text { group }\end{array}$ \\
\hline 2012 [8] & $\begin{array}{l}\text { Retrospective } \\
\text { cohort study }\end{array}$ & $\begin{array}{l}63 \mathrm{IgAN} \text { patients with an } \\
\text { eGFR of }<60 \mathrm{ml} / \mathrm{min} \text { and } \\
\text { proteinuria } \geq 0.5 \mathrm{~g} / \mathrm{d}\end{array}$ & $2-24$ years & $\begin{array}{l}\text { RASI alone group }(n=33) \text {; Combination } \\
\text { group }(n=30 \text { treated with steroids and } \\
\text { RASIs) }\end{array}$ & $\begin{array}{l}\text { Renal function, the amount of proteinuria, } \\
\text { and histological backgrounds were not } \\
\text { significantly different }\end{array}$ \\
\hline 2012 [7] & Meta-analysis & $\begin{array}{l}6 \text { RCTs of combination } \\
\text { therapy with ACEI plus } \\
\text { ARB ( } 109 \text { patients) }\end{array}$ & Not known & $\begin{array}{l}\text { Combined treatment with ACEI plus ARB } \\
\text { VS treatment with ACEI/ARB alone }\end{array}$ & $\begin{array}{l}\text { Combined treatment was more effective } \\
\text { than ACEI/ARB alone for reducing daily } \\
\text { proteinuria }\end{array}$ \\
\hline $2013[6]$ & $\begin{array}{l}\text { Prospective } \\
\text { cohort study }\end{array}$ & $\begin{array}{l}60 \text { patients with IgAN, } \\
\text { proteinuria }<0.5 \mathrm{~g} / \mathrm{d} \text {, } \\
\text { normal blood pressure and } \\
\text { renal function }\end{array}$ & 5 years & Ramipril $2.5 \mathrm{mg}$ daily or no treatment & $\begin{array}{l}\text { Ramipril group does not offer any benefit } \\
\text { by evaluating proteinuria, eGFR and } \\
\text { hypertension }\end{array}$ \\
\hline
\end{tabular}

Table 1: The studies of IgAN treatment with RASIs.

\begin{tabular}{|c|c|c|c|c|c|}
\hline Published time & Research type & Research object & Follow-up time & Treatment & Outcome \\
\hline 1999 [9] & $\begin{array}{l}\text { Prospective } \\
\text { cohort study }\end{array}$ & $\begin{array}{l}86 \mathrm{lgAN} ; \text { urine protein } \\
1.0-3.5 \mathrm{~g} / \mathrm{d}, \mathrm{SCr} \leq 133 \\
\mu \mathrm{mol} / \mathrm{L}(1.5 \mathrm{mg} / \mathrm{dL})\end{array}$ & 5 years & $\begin{array}{l}\text { Supportive therapy alone or steroid } \\
\text { treatment (IV MP } 1 \mathrm{gX} 3 \mathrm{~d} \text { at the beginning } \\
\text { of months } 1,3 \text {, and } 5 \text {, plus oral prednisone } \\
0.5 \mathrm{mg} / \mathrm{kg} \text { on alternate days for } 6 \text { months }\end{array}$ & $\begin{array}{l}20.9 \% \text { in the steroid group and } 32.6 \% \text { in the } \\
\text { control group reached the primary endpoint* } \\
(p<0.048)\end{array}$ \\
\hline 2008 [14] & $\begin{array}{l}\text { Retrospective } \\
\text { cohort study }\end{array}$ & 702 IgAN patients & $\begin{array}{l}\text { Median } 5.1 \\
\text { years }\end{array}$ & $\begin{array}{l}\text { Oral steroids }(n=194), \text { MP pulse therapy } \\
\text { followed by oral prednisolone }(n=34), 474 \\
\text { patients with no steroid }\end{array}$ & $\begin{array}{l}\text { Steroid pulse therapy significantly decreased } \\
\text { the risk of ESRF while oral steroid treatment } \\
\text { did not improve renal survival }\end{array}$ \\
\hline 2009 [10] & $\begin{array}{l}\text { Prospective } \\
\text { cohort study }\end{array}$ & $\begin{array}{l}63 \mathrm{lgAN} \text { patients with } \\
\text { proteinuria of } 1 \text { to } 5 \mathrm{~g} / \mathrm{d} \text {. }\end{array}$ & 4 years & $\begin{array}{l}\text { Cilazapril alone (ACEI group; } n=30 \text { ) or } \\
\text { steroid plus cilazapril (combination group; } \\
n=33 \text { ) }\end{array}$ & $\begin{array}{l}24.1 \% \text { in the ACEI group and } 3 \% \text { in the } \\
\text { combination group reached the primary end } \\
\text { point*. Urine protein excretion significantly } \\
\text { decreased in patients in the combination } \\
\text { group }\end{array}$ \\
\hline 2009 [11] & $\begin{array}{l}\text { Prospective } \\
\text { cohort study }\end{array}$ & $\begin{array}{l}97 \text { IgAN patients with } \\
\text { moderate histologic } \\
\text { lesions, proteinuria } \geq 1.0 \\
\text { g/d; GFR } \geq 50 \mathrm{ml} / \mathrm{min}\end{array}$ & 8 years & $\begin{array}{l}\text { 6-month course of oral prednisone plus } \\
\text { ramipril (combination therapy group) or } \\
\text { ramipril alone (monotherapy group) }\end{array}$ & $\begin{array}{l}26.5 \% \text { in the monotherapy group reached the } \\
\text { primary outcome** compared with } 4.2 \% \text { in the } \\
\text { combination therapy group. The combined } \\
\text { treatment reduced } 24-\text { proteinuria more than } \\
\text { ramipril alone during the first } 2 \text { years }\end{array}$ \\
\hline 2012 [15] & $\begin{array}{l}\text { observational } \\
\text { study }\end{array}$ & $\begin{array}{l}22 \text { active IgAN (median } \\
\text { histological Grade } 3 \text { ) } \\
\text { patients with CKD Stage } 3 \\
-5 \text {; median eGFR } 34.05 \\
\text { ml/min }\end{array}$ & Not known & $\begin{array}{l}\text { Treated with } 500 \mathrm{mg} \text { intravenous MP every } \\
2 \text { weeks for } 6 \text { months. All patients had been } \\
\text { maintained on an ACEI or ARB }\end{array}$ & $\begin{array}{l}73 \% \text { had improvements in the monthly decline } \\
\text { of eGFR. The rate of eGFR decline in the } \\
\text { before treatment period differed significantly } \\
\text { from that in the after treatment period }\end{array}$ \\
\hline
\end{tabular}

Methylprednisolone: MP; * A 50\% increase in baseline serum creatinine level.

** Doubling of baseline serum creatinine or end-stage kidney disease.

Table 2: The studies of IgAN treatment with corticosteroids.

\section{Immunosuppressive Agents}

The treatment of primary IgA nephropathy also includes a series of immunosuppressant therapy (Table 3). A clinical trial which included 40 Chinese IgAN patients with a follow-up of 6 years showed that MMF treatment may result in transient and partial remission of proteinuria in the short-term and renoprotection in the long-term [16]. But an earlier United States trial found no effect on proteinuria [17]. At present, it appears prudent to largely restrict the use of MMF to patients of Asian origin who fail to respond to supportive therapy and/or corticosteroids or in whom the use of steroids is problematic because of comorbidities or side effects. If MMF is used in IgAN patients with a reduced GFR, pneumocystis carinii prophylaxis is important, given several deaths in Chinese IgAN patients on MMF [18]. No recommendation on the use of steroid combined with immunosuppressive therapy is possible in IgAN patients, although a few clinical trials indicate that steroid combined with MMF or azathioprine may have a better response to prevent subsequent progression toward renal failure [19,20]. In 2010, Pozzi et al. published a randomized controlled trial in which 207 IgAN patients with a serum creatinine below $2 \mathrm{mg} / \mathrm{dl}$ and a proteinuria above $1 \mathrm{~g} / \mathrm{d}$, despite RAS blockade, were assigned to receive corticosteroids or additional oral azathioprine. Outcome after a median of 4.9 years was not different between the two groups [21]. In a recent study sirolimus showed a benefit in reducing glomerular proliferative lesions in patients with poor prognosis IgAN [22]. For the refractory IgAN patients, Tacrolimus also showed a rapid proteinuria remission [23] But these promising results should be confirmed in larger RCT clinical trials.

\section{Antithrombotic Agents}

Antithrombotic agents have been widely used in the management of IgAN in Chinese and Japanese populations. A meta-analysis suggested that dipyridamole had statistically significant effects on the reduction of proteinuria but not on the protection of renal function in patients with IgAN. Urokinase had statistically significant effects both on the reduction of proteinuria and on protecting renal function [24]. At present, no recommendation on the use of such drugs is possible in IgAN patients.

\section{Other Treatments}

The benefit of fish oil therapy in patients with IgAN has been controversial. Long-term follow-up of the largest randomized trial so far noted a better preservation of renal function in the fish oil group 


\begin{tabular}{|c|c|c|c|c|c|}
\hline $\begin{array}{l}\text { Published } \\
\text { time }\end{array}$ & Research type & Research object & Follow-up time & Treatment & Outcome \\
\hline 2005 [17] & $\begin{array}{l}\text { Prospective } \\
\text { cohort study }\end{array}$ & $\begin{array}{l}32 \text { North American } \\
\text { lgAN patients with an } \\
\text { eGFR }<60 \mathrm{ml} / \mathrm{min}\end{array}$ & 2 years & $\begin{array}{l}1 \text { year of MMF, titrated up to a dose of } 1000 \mathrm{mg} \text { bid, } \\
\text { or placebo. All patients received RASIs medication }\end{array}$ & $\begin{array}{l}29.4 \% \text { in the MMF group and } 13.3 \% \text { in the } \\
\text { control group reached a } 50 \% \text { increase in } \mathrm{SCr} \\
(\mathrm{P}=0.4) .17 .6 \% \text { in the MMF group and } 13.3 \% \\
\text { in the control group had a } 50 \% \text { reduction in } 24 \\
h \text { proteinuria }\end{array}$ \\
\hline 2010 [21] & $\begin{array}{l}\text { Prospective } \\
\text { cohort study }\end{array}$ & $\begin{array}{l}207 \mathrm{lgAN} \text { patients with } \\
\text { creatinine } \leq 2.0 \mathrm{mg} / \mathrm{dl} \\
\text { and proteinuria } \geq 1.0 \mathrm{~g} / \mathrm{d}\end{array}$ & $\begin{array}{l}\text { median follow- } \\
\text { up of } 4.9 \text { years }\end{array}$ & $\begin{array}{l}\text { A 3-day pulse of MP in months } 1,3 \text {, and } 5 \text { in } \\
\text { addition to both oral prednisone } 0.5 \mathrm{mg} / \mathrm{kg} \text { every } \\
\text { other day and azathioprine } 1.5 \mathrm{mg} / \mathrm{kg} \text { per day for } \\
6 \text { months ( } n=101) \text {. steroids alone on the same } \\
\text { schedule }(n=106)\end{array}$ & $\begin{array}{l}\text { Low-dose azathioprine to corticosteroids for } 6 \\
\text { months does not provide additional benefit to } \\
\text { patients with IgAN and may increase the risk } \\
\text { for adverse events }\end{array}$ \\
\hline 2010 [16] & $\begin{array}{l}\text { Prospective } \\
\text { cohort study }\end{array}$ & $\begin{array}{l}40 \text { Chinese patients with } \\
\text { IgA nephritis }\end{array}$ & 6 years & $\begin{array}{l}\text { All patients were maintained on ARB medication } \\
\text { and half were randomized to receive MMF for } 6 \mathrm{~m}\end{array}$ & $\begin{array}{l}1.5 \% \text { in the MMF group and } 5 \% \text { in the control } \\
\text { group reached the composite end point }{ }^{*} \text {. } \\
\text { Urinary protein excretion and the albumin- } \\
\text { to-creatinine ratio were lower with MMF } \\
\text { treatment during the first } 24 \mathrm{~m}\end{array}$ \\
\hline 2011 [19] & $\begin{array}{l}\text { Prospective } \\
\text { cohort study }\end{array}$ & $\begin{array}{l}22 \text { IgAN patients with } \\
\text { eGFR } \geq 30 \mathrm{ml} / \mathrm{min} \text {, urine } \\
\text { protein } \geq 1 \mathrm{~g} / \mathrm{d}, \mathrm{BP}< \\
130 / 80 \mathrm{mmHg}\end{array}$ & Not known & $\begin{array}{l}\text { Methylprednisolone alone or MP combination with } \\
\text { azathioprine for } 12 \text { months. All the patients were } \\
\text { treated with RASIs and PFA for at least } 6 \mathrm{~m}\end{array}$ & $\begin{array}{l}\text { Two groups seem to be effective in reducing } \\
\text { the severity of proteinuria and stabilizing renal } \\
\text { function. }\end{array}$ \\
\hline 2011 [22] & $\begin{array}{l}\text { Prospective } \\
\text { cohort study }\end{array}$ & $\begin{array}{l}23 \text { IgAN patients with a } \\
\text { GFR within } 30-60 \mathrm{ml} / \\
\text { min and/or proteinuria } \\
>1 \mathrm{~g} / \mathrm{d}\end{array}$ & 1 year & $\begin{array}{l}\text { Low-dose sirolimus plus enalapril and atorvastatin } \\
\text { (SRL group, } n=14 \text { ) or enalapril plus atorvastatin } \\
\text { (CONTROL group, } n=9 \text { ) }\end{array}$ & $\begin{array}{l}\text { Primary end point }{ }^{* *} \text { improved significantly } \\
\text { in the SRL group at } 12 \text { months. Proteinuria } \\
\text { decreased similarly in both study groups }\end{array}$ \\
\hline 2012 [23] & $\begin{array}{l}\text { Prospective } \\
\text { cohort study }\end{array}$ & $\begin{array}{l}14 \text { refractory IgAN } \\
\text { patients }\end{array}$ & Not known & $\begin{array}{l}\text { Tacrolimus }(0.05-0.1 \mathrm{mg} / \mathrm{kg} / \mathrm{d}) \text { and prednisone }(0.5 \\
\mathrm{mg} / \mathrm{kg} / \mathrm{d}) \text { for at least } 6 \mathrm{~m}\end{array}$ & $\begin{array}{l}9 \text { patients showed complete or partial } \\
\text { remission and } 7 \text { patients achieved remission } \\
\text { within } 1 \mathrm{~m}\end{array}$ \\
\hline
\end{tabular}

* Serum creatinine doubling or end-stage renal disease.

** Variation of hematuria, proteinuria and blood pressure.

Table 3: The studies of IgAN treatment with immunosuppressive agents

[25]. A small Japanese clinical trial in the IgAN patients showed a significant improvement in estimated creatinine clearance in fish oil group ( $1.8 \mathrm{~g} / \mathrm{d}$ for 12 months), but not in the control group. No side effects were noted. All the patients were treated by the assessment based on the Japanese Society of Nephrology classification system for IgA nephropathy. This trial indicated that fish oil therapy was a safe and worthwhile supplement to the drugs used to treat IgAN [26]. In contrast, a meta-analysis which included five RCTs (239 patients) suggested that there were insufficient data to confirm the efficacy of fish oil therapy for proteinuria and renal function in IgA nephropathy [27]. Further large scale trials are needed to shed more light on this issue.

Several studies in Japan reported that Tonsillectomy was associated with a favorable renal outcome of IgA nephropathy in terms of clinical remission and delayed renal deterioration even in non-steroid-treated patients $[28,29]$. A retrospective study showed that tonsillectomy and steroid-pulse (TSP) therapy increased the probability of CR compared with tonsillectomy alone in IgAN patients with urinary abnormalities [30]. However, no recommendation on the use of tonsillectomy is possible in IgAN patients.

\section{Therapeutics Strategy}

Here we will review the available treatments from the perspective of each clinical presentation encountered in IgAN.

For the IgAN patients with isolated microscopic hematuria and little or no proteinuria $(<0.5 \mathrm{~g} / \mathrm{d})$, no specific treatment is required if they have normal GFR and no hypertension, although patients should receive a follow-up at least for 10 years.

For the IgAN patients with proteinuria more than $0.5-1 \mathrm{~g} / \mathrm{d}$, supportive treatment for 3-6 months should be received no matter whether they have decreased GFR or hypertension. During follow-up, to the patients with a GFR level of more than $50 \mathrm{ml} / \mathrm{min}$, combined with corticosteroid therapy may be considered if the level of proteinuria persists for more than $1 \mathrm{~g} / \mathrm{d}$.

Acute kidney injury often occurs with macroscopic hematuria. Renal biopsy should be given because that will distinguish acute kidney injury between acute tubular necrosis and crescentic IgAN. Acute tubular necrosis would be self-limiting with continuing supportive treatment while the crescentic IgAN needs high-dose corticosteroids and cyclophosphamide combined with support treatment, and in some cases, using plasma exchange.

For the patients with nephrotic syndrome, IgAN with minimal change nephropathy should be treated similar to the minimal-change disease. There are few RCTs about the treatment strategies of other types of IgAN with nephrotic syndrome. But one point is important, that is the indiscriminate use of corticosteroid should be discouraged.

\section{Conclusions}

There still remain many problems in treatment of $\operatorname{IgAN}$ to resolve, such as the efficacy and safety of corticosteroid, the use of immunosuppressive agents, the treatment strategies in patients with nephrotic syndrome and so on. Now the ongoing TESTING Study, sponsored by The George Institute and collaborated by Peking University First Hospital, will evaluate the long-term efficacy and safety of oral methylprednisolone on a background of routine RAS inhibitor therapy, in preventing kidney events in patients with IgA nephropathy and features suggesting a high risk of progression. But still other large RCTs are needed for the development of treatment in the primary IgAN.

\section{References}

1. Donadio JV, Grande JP (2002) IgA nephropathy. N Engl J Med 347: 738-748.

2. Barratt J, Feehally J (2005) IgA nephropathy. J Am Soc Nephrol 16: 2088-2097.

3. KDIGO clinical practice guideline for glomerulonephritis. Kidney Internationa Supplements (2012) 2: 143-153. 
4. Woo KT, Chan CM, Tan HK, Choong HL, Foo M, et al. (2009) Beneficial effects of high-dose losartan in IgA nephritis. Clin Nephrol 71: 617-624.

5. Moriyama T, Amamiya N, Ochi A, Tsuruta Y, Shimizu A, et al. (2011) Long-term beneficial effects of angiotensin-converting enzyme inhibitor and angiotensin receptor blocker therapy for patients with advanced immunoglobulin A nephropathy and impaired renal function. Clin Exp Nephrol 15: 700-707.

6. Li PK, Kwan BC, Chow KM, Leung CB, Szeto CC (2013) Treatment of early immunoglobulin $A$ nephropathy by angiotensin-converting enzyme inhibitor. Am J Med 126: 162-168.

7. Cheng J, Zhang X, Tian J, Li Q, Chen J (2012) Combination therapy an ACE inhibitor and an angiotensin receptor blocker for IgA nephropathy: a metaanalysis. Int J Clin Pract 66: 917-923.

8. Moriyama T, Nakayama K, Ochi A, Amemiya N, Tsuruta Y, et al. (2012) Comparison of inhibitors of renin-angiotensin-aldosterone system (RAS) and combination therapy of steroids plus RAS inhibitors for patients with advanced immunoglobulin A nephropathy and impaired renal function. Clin Exp Nephro 16: 231-237.

9. Pozzi C, Bolasco PG, Fogazzi GB, Andrulli S, Altieri P, et al. (1999) Corticosteroids in IgA nephropathy: a randomised controlled trial. Lancet 353 883-887.

10. Lv J, Zhang H, Chen Y, Li G, Jiang L, et al. (2009) Combination therapy of prednisone and ACE inhibitor versus ACE-inhibitor therapy alone in patients with IgA nephropathy: a randomized controlled trial. Am J Kidney Dis 53: 26-32.

11. Manno C, Torres DD, Rossini M, Pesce F, Schena FP (2009) Randomized controlled clinical trial of corticosteroids plus ACE-inhibitors with long-term follow-up in proteinuric IgA nephropathy. Nephrol Dial Transplant 24: 3694 3701.

12. Lv J, Xu D, Perkovic V, Ma X, Johnson DW, et al. (2012) Corticosteroid therapy in IgA nephropathy. J Am Soc Nephrol 23: 1108-1116.

13. Hogg RJ, Lee J, Nardelli N, Julian BA, Cattran D, et al. (2006) Clinical trial to evaluate omega- 3 fatty acids and alternate day prednisone in patients with $\lg A$ nephropathy report from the Southwest Pediatric Nephrology Study Group. Clin J Am Soc Nephrol 1: 467-74

14. Katafuchi R, Ninomiya T, Mizumasa T, Ikeda K, Kumagai $H$, et al. (2008) The improvement of renal survival with steroid pulse therapy in IgA nephropathy. Nephrol Dial Transplant 23: 3915-3920.

15. Kim TY, Kim SB, Park SK (2012) The efficacy of steroid pulse therapy in patients with IgA nephropathy. Clin Nephrol 78: 100-105.

16. Tang SC, Tang AW, Wong SS, Leung JC, Ho YW, et al. (2010) Long-term study of mycophenolate mofetil treatment in IgA nephropathy. Kidney Int 77 543-549.

17. Frisch G, Lin J, Rosenstock J, Markowitz G, D'Agati V, et al. (2005) Mycophenolate mofetil (MMF) vs placebo in patients with moderately advanced
IgA nephropathy: a double-blind randomized controlled trial. Nephrol Dial Transplant 20: 2139-2145.

18. Lv J, Zhang H, Cui Z, Su T, Zhang Y, et al. (2008) Delayed severe pneumonia in mycophenolate mofetil-treated patients with IgA nephropathy. Nephrol Dial Transplant 23: 2868-2872.

19. Stangou M, Ekonomidou D, Giamalis $\mathrm{P}$, Liakou H, Tsiantoulas A, et al. (2011) Steroids and azathioprine in the treatment of IgA nephropathy. Clin Exp Nephrol 15: 373-380

20. Roccatello D, Rossi D, Marletto F, Naretto C, Sciascia S, et al. (2012) Long term effects of methylprednisolone pulses and mycophenolate mofetil in IgA nephropathy patients at risk of progression. J Nephrol 25: 198-203.

21. Pozzi C, Andrulli S, Pani A, Scaini P, Del Vecchio L, et al. (2010) Addition of azathioprine to corticosteroids does not benefit patients with IgA nephropathy J Am Soc Nephrol 21: 1783-1790.

22. Cruzado JM, Poveda $R$, Ibernón M, Díaz M, Fulladosa X et al. (2011) Lowdose sirolimus combined with angiotensin-converting enzyme inhibitor and statin stabilizes renal function and reduces glomerular proliferation in poor prognosis IgA nephropathy. Nephrol Dial Transplant 26: 3596-3602.

23. Zhang Q, Shi SF, Zhu L, Lv JC, Liu LJ, et al. (2012) Tacrolimus improves the proteinuria remission in patients with refractory IgA nephropathy. Am J Nephrol 35: $312-320$

24. Liu XJ, Geng YQ, Xin SN, Huang GM, Tu XW, et al. (2011) Antithrombotic drug therapy for IgA nephropathy: a meta analysis of randomized controlled trials. Intern Med 50: 2503-2510.

25. Donadio JV Jr, Grande JP, Bergstralh EJ, Dart RA, Larson TS, et al. (1999) The long-term outcome of patients with IgA nephropathy treated with fish oil in a controlled trial. Mayo Nephrology Collaborative Group. J Am Soc Nephrol 10: $1772-1777$.

26. Uchiyama-Tanaka Y, Mori Y (2010) Effects of eicosapentaenoic acid supplementation on immunoglobulin A nephropathy. Ther Apher Dial 14: 303 307.

27. Liu LL, Wang LN (2012) Ï\%o-3 fatty acids therapy for IgA nephropathy: a metaanalysis of randomized controlled trials. Clin Nephrol 77: 119-125.

28. Maeda I, Hayashi T, Sato KK, Shibata MO, Hamada M, et al. (2012) Tonsillectomy has beneficial effects on remission and progression of $\lg A$ nephropathy independent of steroid therapy. Nephrol Dial Transplant 27: 28062813.

29. Komatsu H, Fujimoto S, Kikuchi M, Sato Y, Kitamura K (2012) Tonsillectomy delays progression of advanced IgA nephropathy to end-stage kidney disease. Ren Fail 34: 448-453.

30. Nakagawa N, Kabara M, Matsuki M, Chinda J, Fujino T, et al. (2012) Retrospective comparison of the efficacy of tonsillectomy with and withou steroid-pulse therapy in IgA nephropathy patients. Intern Med 51: 1323-1328.

This article was originally published in a special issue, Kidney Diseases \& Treatment handled by Editor(s). Dr. Qian Qi, Mayo Clinic College of Medicine, United States 